\title{
Exploring Academic Motivation, Academic Self-efficacy and Attitudes toward Teaching in Pre-service Early Childhood Education Teachers
}

\author{
Emine Ferda Bedel \\ Correspondence: Emine Ferda Bedel, Canakkale Onsekiz Mart University, Turkey \\ Received: October 17, 2014 Accepted: November 10, 2014 Online Published: October 12, 2015 \\ doi:10.11114/jets.v4i1.561 \\ URL: http://dx.doi.org/10.11114/jets.v4i1.561
}

\begin{abstract}
This study is designed to explore academic motivation, academic self-efficacy and attitudes toward teaching in pre-service early childhood education teachers and to investigate the relationships among those variables. Data were gathered through questionnaires administered to 251 pre-service early childhood education teachers. Results indicated that academic motivation was significantly related to academic self efficacy. Although participants had high levels of positive attitudes toward teaching, those attitudes neither related to the academic motivation nor to the academic self efficacy. In addition, regression analyses revealed that academic self-efficacy was the only meaningful predictor of academic motivation.
\end{abstract}

Keywords: academic motivation, academic self-efficacy, teaching attitudes, early childhood pre-service teachers

\section{Introduction}

Contemporary educational literature reflects an international concern for improving the quality of teacher education programs in order to promote better school outcomes for students. Despite the general acceptance of social constructivism by educational theorists and practitioners as a useful framework for effective teaching, current teacher education programs lack a component that focuses on pre-service teachers' diverse belief systems and perceptions (Raths, 2001; Rimm-Kaufman \& Sawyer, 2004). Literature review reveals that the examination of educational beliefs and attitudes of pre-service teachers is important due to at least two reasons: First, as a student, pre-service teachers' beliefs and attitudes impact their academic success (Akey, 2006; Pajares, 1992). For instance, students who believe in their capability or efficacy are more motivated and more likely to engage in learning activities (Pintrich, 2003). And second, pre-service teachers' beliefs have a major influence on their teaching process when they begin to teach (Garvis, Fluckiger \& Twigg, 2011; Raths, 2001). Thus; understanding of motivation, efficacy beliefs and attitude toward teaching in pre-service teachers have potential importance for the improvement of educational quality.

\subsection{Academic Motivation}

Motivation is among the most important and widely studied concepts in educational research because of its strong connection with academic outcomes such as learning and achievement (Fortier, Vallerand, \& Guay, 1995; Green et al., 2006; Vallerand et al., 1992; Vansteenkiste, Lens \& Deci, 2006). To understand academic motivation, educational researchers have adopted a number of theoretical approaches including the expectancy-value model, attribution theory, goal orientation theory, and self-determination theory (Opdenakker, Maulana \& den Brok, 2012). Among these, Self Determination Theory (SDT) of academic motivation by Deci and Ryan $(1985,2000,2008)$ is viewed as a sound framework for explaining the differences among students in terms of learning strategies, persistence and performance (Vallerand et al., 1992; Vansteenkiste, Lens \& Deci, 2006) and for linking motivation to educational environments such as the classroom climate (Opdenakker, Maulana \& den Brok, 2012; Vansteenkiste, Lens \& Deci, 2006).

In a recent conceptualization of SDT, three types of motivational construct have been proposed: (1) Autonomous motivation refers to engaging in an activity with a sense of volition and self-endorsement and includes intrinsic motivation and well internalized forms of extrinsic motivation. (2) Controlled motivation consists of both external regulation such as reward and punishment and introjected regulation in which a partial internalization has occurred because of the desire for approval, avoidance of shame and self-esteem. (3) Amotivation denotes absence of intention and motivation (Deci \&Ryan, 2008, 2010).

Vallerand et al. (1992) designed a scale to measure the tenets of self-determination theory. Subsequent to the first version of the scale in French, the English adaptation of the scale has been developed and named as Academic 
Motivation Scale (AMS) (Cokley, et al., 2001). Consequently, the AMS has been translated into different languages (e.g., Italian version by Alivernini \& Lucidi, 2008, Turkish version by Karagüven, 2012; Spanish version by Núñez, 2010; German version by Wilkesmann, Fischer, \& Virgillito, 2012). As such, SDT has generated a great deal of research in the field of education across diverse cultures (Vallerand et al., 1992). For instance, Sahin and Çakar (2011) examined the academic motivation in Turkish pre-service teachers. They found no significant differences at the levels of academic motivation by gender and academic achievement. On the other hand, in a study with American college students, females had higher levels of overall motivation as well as intrinsic and extrinsic motivation (Brouse et al., 2010).

SDT researchers have also explored how social contexts relate to motivational processes. Social contexts that support autonomy draw on giving timely positive feedback, taking learners' perspectives into account, allowing learners their own choice and self-initiative behaviors; while avoiding the use of pressures and contingencies to direct behavior. On the other hand, controlling contexts include overtly coercive strategies and overtly controlling language (Vansteenkiste, Lens \& Deci, 2006). Although both autonomous motivation and controlled motivation direct behavior, the former leads to better psychological health, performance and longer persistence whereas the latter yields experience of pressure and obligation.

\subsection{Academic Self-efficacy}

Within the framework of Social Cognitive Theory by Bandura (1997) self-efficacy is viewed as a core construct and defined as "belief in one's capabilities to organize and execute the courses of action required to produce given attainments" (p.3). Research on self-efficacy suggests that people with higher levels of self-efficacy tend to pursue challenging goals and to have strong commitment even when they encounter with difficulties. On the contrary, people with lower levels of self-efficacy are more likely to avoid difficult tasks, have less commitment and effort to pursue their personal goals, and are more vulnerable to stress and depression (Bandura, 1993).

Within educational research, in addition to studies dealing with general self-efficacy beliefs, specific self-efficacy domains such as teacher self-efficacy and academic self-efficacy have been conceptualized and measured. Skaalvik and Skaalvik (2007) define teacher-self efficacy as "individual teachers' beliefs in their own abilities to plan, organize, and carry out activities required to attain given educational goals (p.612). Teacher self-efficacy was found to be associated with teachers' classroom behaviors and performance (e.g., Rimm-Kaufman \& Sawyer, 2004) as well as with their students' learning and motivation (e.g., Mojavezi \& Tamiz, 2012; Yi-Hsiang, 2014).

As another specific domain of self-efficacy, academic self-efficacy refers to a student's perception regarding competence in learning and performing academic tasks (Schunk \& Pajares, 2002). It must be mentioned that academic self-efficacy is similar to but distinct from academic self-concept which refers to "individuals' knowledge and perceptions about themselves in achievement situations" (Bong \& Skaalvik, 2003, p.6). Ferla, Valcke and Cai's (2009) research indicates that academic self-efficacy and academic self-concept were two correlated but conceptually and empirically distinct psychological constructs. Their findings further revealed that academic self-efficacy was a stronger predictor of academic achievement whereas academic self-concept had more influence on motivational variables. A study by Zajacova, Lynch and Espenshade (2005) showed that academic self-efficacy was a better predictor of academic success than stress in college freshman.

Self-efficacy is examined in relation to gender, as well. A meta-analysis including 247 studies demonstrates that males had slightly higher academic self-efficacy beliefs compared to females. In addition, self-efficacy beliefs differed by the subject area indicating that males showed greater efficacy beliefs in mathematics, social sciences and computer whereas females displayed higher efficacy beliefs in language arts (Huang,2013).

\subsection{Attitudes toward Teaching}

Attitudes are defined as "a set of beliefs that we hold in relation to an attitude object, where an attitude object is a person, thing, event, or issue" (Crisp \& Turner, 2010, p.72). Because, teacher attitudes are considered as an important factor that influences their performance (Rimm-Kaufman \& Sawyer, 2004), attitudes regarding a variety of subjects have been examined in pre-service or in-service teachers including teachers teaching mathematics (e.g., Jong \& Hodges, 2013), teaching science (Murphy \& Smith,2012; Sundberg \& Ottander,2013) and technology, (e.g., Abdulrasool \& Mishra, 2010; Johnson \& Howell, 2005). Nevertheless, there exists limited number of studies examining attitudes directly related to teaching itself or the teaching profession. These studies indicate that regardless of their teaching subject, teachers or pre-service teachers have generally positive attitudes toward their profession. Bozdoğan, Aydın and Yıldırım (2007) investigated attitudes toward teaching in pre-service teachers majoring in science education and social science education. Their findings indicated that female students had more positive attitudes toward teaching and there was no significant difference between social science education pre-service teachers and science education pre-service teachers. In another study, the relationship between attitudes toward teaching and level of anxiety was examined in senior school of education students. The findings indicated that the participants had positive attitudes toward the 
teaching profession and students with more positive attitudes had lower levels of anxiety (Doğan \& Çoban 2009). Çağlar (2013) found a negative association between the level of alienation and attitudes towards the teaching profession in 875 pre-service teachers. In a study by Özder, Konedralı and Zeki (2010), pre-service early childhood teachers had higher scores of attitudes toward teaching than those of pre-service primary school teachers. Another finding of this study was that attitudes toward teaching were not related to academic success as measured by GPA.

\subsection{The Present Study}

Social Cognitive Theory suggests a connection between self-efficacy and motivation, since individuals' outcome expectations rely on their evaluations of their performance in given situations (Bandura, 1986). The proposed linkage between self-efficacy and motivation has been supported by research data. In a study by Chowdhury and Shahabuddin (2007) self-efficacy was significantly related to both internal and external motivation in college students. Another significant positive correlation between self-efficacy and intrinsic motivation was reported by Walker, Greene and Mansell (2006) in college students. They also found a significant negative correlation between self-efficacy and amotivation. McGeown et al. (2004) explored, to what extent age, gender, SES, personality and self-efficacy predict internal and external academic motivation. Their findings indicated that self-efficacy is the best predictor of intrinsic and academic motivation.

Some studies have examined the relationship between academic or teacher self-efficacy beliefs and attitudes toward teaching. Bümen and Özaydın (2014) conducted a longitudinal study to explore the changes in teacher self-efficacy and attitudes towards teaching profession through the four-year pre-service teacher education program. They found a significant increase in self-efficacy beliefs and no significant increase in attitudes toward teaching throughout the process. İpek and Camadan (2012) found no relationship between attitude toward teaching profession and teacher self-efficacy in pre-service teachers. Demirtaş, Cömert, Özer (2011) investigated the relationship between attitudes and teacher self-efficacy beliefs in senior pre-service students from different majors. As a result, they reported a positive but low association between these two variables.

The current study investigates the academic motivation, academic self-efficacy and attitudes toward teaching in early childhood pre-service teachers and explores the relationships among those variables. Understanding of belief systems and attitudes in pre-service early childhood teachers is especially important because young children are more likely to benefit from role models with positive beliefs and attitudes and to be badly influenced by those with negative ones. In addition, no published studies were found assessing the relationship between academic motivation and attitudes toward teaching or simultaneous influence of academic self-efficacy, attitudes toward teaching, class level and gender on academic motivation. Thus, the following research questions were investigated in this study:

1. What relationship, exists between academic motivation, academic motivation subscales, academic self-efficacy and attitudes toward teaching?

2. To what extent, if any, is the academic motivation influenced by the academic self-efficacy, attitudes toward teaching, class level and gender, when examined simultaneously?

\section{Method}

\subsection{Participants}

251 Turkish pre-service early childhood education teachers were involved in this study. Of the participants $212(85 \%)$ were females and 38 (15\%) were males. 77 freshman, 35 sophomore, 72 junior and 67 senior students were included.

\subsection{Measures}

In the current study, three Likert-type scales: Academic Motivation Scale, Academic Self-efficacy Scale and Attitudes toward Teaching Scale were used to collect data. Additionally, the participants were asked to specify their gender and class level.

\subsubsection{Academic Motivation Scale (AMS)}

Academic Motivation Scale is a 20 item, Likert-type scale developed by Bozanoğlu (2004). The scale includes three factors: Exploration, Using Knowledge and Self-exceeding. Bozanoğlu states that factor factorial structure of this scale has a similar structure with the Academic Motivation Scale developed by Vallerand et al. (1992). The scores can be obtained from the scale ranges between 20 and 100, with higher scores being indicative of higher academic motivation. The reported Cronbach's alpha coefficients ranged from .77 to .86 . For the current study, Cronbach's alpha coefficient was .91.

\subsubsection{Academic Self-efficacy Scale (ASES)}

The original Academic Self-efficacy Scale was developed by Jerusalem and Schwarzer (1981) and adapted to Turkish 
by Yılmaz, Gürçay and Ekici (2007). The adapted scale encompasses 7 items as the original version. For the scale, the highest possible score is 28 and the lowest possible score is 7, with higher scores indicating higher levels of academic self-efficacy belief. The reported Cronbach's alpha coefficient was .79. The Cronbach's alpha coefficient was found as .78 for the current study.

\subsubsection{Attitude toward Teaching Scale (ATTS)}

Attitude toward Teaching Scale is a Likert-type response scale developed by Erkuş et al. (2000). The scale includes 23 items and Cronbach alpha coefficient of the scale reliability is reportedly .99. For the current study, Cronbach's alpha coefficient was found as .87 .

\subsection{Procedure and Data Analysis}

The participants completed Academic Motivation Scale, Academic Self-efficacy Scale and Attitudes toward Teaching Scale. Participation in the study was voluntary and data was collected during regular class hours from the students in attendance. Approximately, students spent 20 to 25 minutes to fill out the instruments. The SPSS software (version 18.0) was used to calculate descriptive statistics, correlations and regression analyses.

\section{Results}

Descriptive statistics (means, standard deviations) and correlation coefficients were computed for the variables. In addition a regression analysis was performed in order to see simultaneous influences of academic self-efficacy, attitudes toward teaching, class level and gender on academic motivation.

\subsection{Descriptive Statistics and Correlations}

As seen from the Table 1, mean for the ATTS was $3.56(n=243, S d=.59)$, for ASES was $3.98(n=248, S d=.49)$, and for overall AMS was 3.45 ( $\mathrm{n}=243$, $\mathrm{Sd}=.62)$.

Table1. Means, Standard Deviations and Correlations

\begin{tabular}{llllllllll}
\hline Variables & $\mathrm{N}$ & $\bar{X}$ & $\mathrm{Sd}$ & $(1)$ & $(2)$ & $(3)$ & $(4)$ & $(5)$ & $(6)$ \\
\hline 1.Attitude toward Teaching & 243 & 3.56 & .59 & - & & & & \\
2.Academic Self-efficacy & 248 & 3.98 & .49 & -04 & - & & & \\
3.Academic Motivation & 243 & 3.45 & .62 & -.01 & $.53^{* *}$ & - & & \\
4.Exploration & 248 & 3.20 & .71 & .00 & $.51^{* *}$ & $.91^{* *}$ & - & & \\
5.Using Knowledge & 246 & 3.90 & .61 & .05 & $.43^{* *}$ & $.87^{* *}$ & $.71^{* *}$ & - & \\
6.Self-exceeding & 248 & 3.30 & .74 & -.03 & $.49^{* *}$ & $.90^{* *}$ & $.72^{* *}$ & $.69^{* *}$ & - \\
\hline
\end{tabular}

Academic Motivation scores were significantly relate to academic self-efficacy scores ( $r=.53, p<.01)$. In addition, all academic motivation sub-scales are significantly related to Academic Self-efficacy $(r=.51, p<.43 ; r=.49, p<.01 ; \quad r=.53$, $\mathrm{p}<.01$ ), respectively. Statistical analyses failed to corroborate significant correlations between attitudes toward teaching and academic motivation scales.

\subsection{Regression Analyses}

A multiple linear regression analysis was performed with Academic Motivation as the dependent variable and Attitudes toward Teaching, Academic Self-Efficacy, class level (freshmen, sophomore, junior and senior) and gender as the independent variables. This initial regression analysis provided an examination of all variables entered in the regression equation, regardless of their statistical significance. Collinearity diagnostics from the regression output revealed no collinearity problem. In addition, assumptions were met regarding linearity, homoscedasticity and normality of residuals. Table 2 displays those results.

Table 2. Summary of Regression Results with Gender, Class Level, Attitudes toward Teaching and Academic Self-efficacy Entered for Full Model Explaining Academic Motivation

\begin{tabular}{lllllll}
\hline Independent Variables & B & SE b & B & Partial & t & P \\
\hline Attitude toward Teaching & .006 & .061 & .006 & .006 & .097 & .923 \\
\hline Academic Self-efficacy & .691 & .070 & .545 & .544 & 9.83 & .000 \\
\hline Class Level & -035 & .030 & -.066 & -.077 & -1.16 & .244 \\
\hline Gender & .029 & .081 & .020 & .024 & .357 & .721 \\
\hline $\mathrm{F}=24.34$ & & Multiple R $=.54$ & & \\
$\mathrm{df}=4 / 230$ & & R Square $=30 \%$ & & \\
$\mathrm{p}=.000$ & & Adj. R Square $=28 \%$ & & \\
\hline
\end{tabular}

Using enter method, a significant model emerged $\left(\mathrm{F} 4-230=24.34, \mathrm{p}<.001, \mathrm{R}^{2}=28\right)$. All together, the independent variables explained $30 \%$ of the academic motivation. However, only one variable, academic self-efficacy had statistically 
significant predictive effect on academic motivation. Subsequently, a Stepwise regression analysis was used to determine the individual contribution of academic self-efficacy in predicting academic motivation. A reduced model explaining the predictive ability of academic self-efficacy is presented in Table 3.

Table 3. Summary of Regression Results with Personality Factors Entered for Final Model Explaining Attitudes Toward Teaching

\begin{tabular}{lllllllllll}
\hline Model & $\begin{array}{l}\text { Independent } \\
\text { Variable }\end{array}$ & $\mathbf{B}$ & $\mathbf{S E} \mathbf{b}$ & $\mathbf{B}$ & $\mathbf{T}$ & $\mathbf{p}$ & $\mathbf{R}$ & $\mathbf{R}^{2}$ & $\mathbf{F}$ & $\mathbf{P}$ \\
\hline $\mathbf{1}$ & $\begin{array}{l}\text { Academic } \\
\text { Self-efficacy } \\
\text { Constant }\end{array}$ & .679 & .070 & .532 & 9.72 & .000 & .532 & .283 & 94.64 & 000 \\
& 1.43 & .210 & -- & 6.81 & .000 & & & & \\
\hline
\end{tabular}

The reduced model indicates that Academic Self-efficacy explained approximately $28 \%$ of the variance in Academic Motivation scores $(\mathrm{F} 1,240=94.64, \mathrm{p}<.001)$.

\section{Discussion}

The participants of this study displayed above average scores in terms of academic motivation, academic self-efficacy and attitude toward teaching, indicating that pre-service early childhood teachers included in this study tended to perceive themselves as academically motivated and efficacious in addition to holding positive attitudes toward teaching. This result is consistent with previous research in which pre-service teachers displayed relatively high scores in teaching attitudes (e.g., Erkuş et al., 2000; Özder, KonedralI and Zek1, 2010).

As proposed by Social Cognitive Theory (Bandura, 1986) and supported by previous research findings, (e.g., Chowdhury and Shahabuddin, 2007; McGeown et al., 2004; McGeown et al., 2004), some medium to strong associations among academic motivation (and all of its sub-scales) and academic self-efficacy were found in the current study, with correlation coefficients ranging from .43 to .53 .

Moreover, the results demonstrated that neither academic motivation nor academic self-efficacy was significantly related to attitudes toward teaching. Previous research indicates no significant relationship (İpek \& Camadan, 2012) or significant but low association (Demirtaş, Cömert \& Özer, 2011) between attitudes toward teaching and self-efficacy beliefs. Another study by Rimm-Kaufman and Sawyer (2004) reported that after implementation of an improvement program, attitudes toward teaching scores were significantly related to some aspects of efficacy beliefs (efficacy to create a positive classroom climate and efficacy to influence decision making), but not associated with other aspects such as disciplinary and self-efficacy instructional self-efficacy. Therefore, more research is needed for a better clarification of the possible link between academic motivation, efficacy beliefs and attitudes toward teaching.

In the current study, gender was not a predictor of academic motivation. Ryan and Deci (2000) report that females tend to have higher levels of motivation. A study by Brouse et al. (2010) in which American college students' academic motivation was examined in relation to gender, class and source of payment, revealed that females had higher levels of academic motivation. Similarly, Vecchione, Alessandri and Marsicano (2014) found that among Italian students, females had higher academic motivation scores. On the other hand, Şahin and Çakar (2011) found no significant gender difference in their study with Turkish pre-service teachers. Therefore, more research is needed to clarify gender differences in academic motivation, considering also cultural differences and measurement tools.

It seems reasonable to expect that students will have increased levels of academic motivation as they progress through their training program because of teaching experience, which supposedly offers more opportunity to be autonomous. However, grade was not a predictor of academic motivation in the current study group. To some degree, this finding is not consistent with other studies. Deci and Ryan (2000) state that the levels of intrinsic motivation decrease from freshman years to senior years, whereas Brouse et al. (2010) found that students' motivation declined with the years they spent in college. Taken together, these results suggest that teacher training programs need to focus on how teacher practicum courses will have positive contributions in shaping belief systems in pre-service teachers.

Perhaps like other types of beliefs, self-efficacy beliefs are formed through personal experiences and persuasions received from others (Bandura, 1986). Being a significant socialization agent and a role model, pre-service teachers' beliefs and attitudes have potential to shape the beliefs and conceptualizations of young children. As mentioned earlier, some studies demonstrated that once recognized, beliefs can be altered (e.g. Rimm-Kaufman \& Sawyer, 2004). For example, Wagner and Szamosközi's (2012) meta-analytic study in which they determine the effectiveness of academic motivation enhancement programs demonstrated that intervention programs targeting several motivational factors at the same time were more effective. Therefore, pre-service teacher training programs should help teacher candidates to identify and reflect on their belief systems and transform them when necessary.

There are some limitations in this study. An important restraint of this study is that the measurement of academic motivation, academic self-efficacy and attitudes toward teaching was limited to the instruments' validity and reliability. 
Self-assessment measures of teacher beliefs may not reflect the real situation due to such factors as social desirability or misevaluation of self-beliefs. In the current study, academic motivation and self-efficacy beliefs are considered as domain-general. On the other hand, students would have varying levels of academic motivation and efficacy beliefs by different academic subjects. In addition, the sample selection consists of 251 participants from one college. A larger sample size recruited from various early childhood teacher training programs, use of additional measurement methods such as observations, qualitative methods or performance based assessments and longitudinal research designs would provide some further insight in understanding and conceptualizing the belief systems of teachers.

\section{References}

Abdulrasool, S. M., \& Mishra, R. R. (2010). Teachers' attitude towards integration of computer assisted instructions in teaching and learning process in CAD/CAM/CNC module. International Journal of Learning, 16(12), 137-148.

Akey, T. M. (2006). School Context, Student Attitudes and Behavior, and Academic Achievement: An Exploratory Analysis. MDRC

Alivernini, F., \& Lucidi, F. (2008). The Academic Motivation Scale (AMS): Factorial structure, invariance and validity in the Italian context. Testing, Psychometrics, Methodology in Applied Psychology, 15(4), 211-220.

Bandura, A. (1986). Social foundations of thought and action: A social cognitive theory. Englewood Cliffs, NJ Prentice-Hall.

Bandura, A. (1993). Perceived self-efficacy in cognitive development and functioning. Educational Psychologist, 28, 117-148. http://dx.doi.org/10.1207/s15326985ep2802_3

Bandura, A. (1997). Self Efficacy: The exercise of control. New York: Freeman.

Bong, M., \& Skaalvik, E. M. (2003). Academic self-concept and self-efficacy: How different are they really?. Educational psychology review, 15(1), 1-40. http://dx.doi.org/10.1023/A:1021302408382

Bozanoğlu, İ. (2004). Akademik güdülenme ölçeği: Geliştirmesi, geçerliği, güvenirliği. Ankara Üniversitesi Eğitim Bilimleri Fakültesi Dergisi, 37(2), 83-98. http://dx.doi.org/10.1501/egifak_0000000094

Bozdoğan, A. E., Aydın, D., \& Yıldırım, K. (2007). Öğretmen adaylarının öğretmenlik mesleğine ilişkin tutumları. Ahi Evran Üniversitesi Kırşehir Eğitim Fakültesi Dergisi (KEFAD), 8(2), 83-97.

Brouse, C. H., Basch, C. E., LeBlanc, M., McKnight, K. R., \& Lei, T. (2010). College students' academic motivation: differences by gender, class, and source of payment. College Quarterly, 13(1), n1.

Bümen, N., \& Özaydin, T. (2014). Changes on teacher self-efficacy and attitudes towards teaching profession from candidacy to induction. Education and Science, 38(169), 109-125.

Çağlar, C. (2013). Eğitim fakültesi öğrencilerinin yabancılaşma düzeyleri ile öğretmenlik mesleğine yönelik tutumları arasındaki iliş̧i. Kuram ve Uygulamada Eğitim Bilimleri, 13(3), 1497.

Chowdhury, M. S., \& Shahabuddin, A. M. (2007). Self-efficacy, motivation and their relationship to academic performance of bangladesh college students. College Quarterly, 10(1), 1-9.

Cokley, K. O., Bernard, N., Cunningham, D., \& Motoike, J. (2001). A psychometric investigation of the academic motivation scale using a united states sample. Measurement and Evaluation in Counseling and Development. 34, 109-119.

Crisp, R. J., \& Turner, R. N. (2010). Essential Social Psychology. 2nd ed. London: Sage

Deci, E. L., \& Ryan, R. M. (1985). Instrinsic Motivation and Self - determination in Human Motivation, Plenum Press, New York, NY. http://dx.doi.org/10.1007/978-1-4899-2271-7

Deci, E. L., \& Ryan, R. M. (2000). The" what" and" why" of goal pursuits: Human needs and the self-determination of behavior. Psychological inquiry, 11(4), 227-268. http://dx.doi.org/10.1207/S15327965PLI1104_01

Deci, E. L., \& Ryan, R. M. (2008). Self-determination theory: A macrotheory of human motivation, development, and health. Canadian Psychology/Psychologie canadienne, 49(3), 182. http://dx.doi.org/10.1037/a0012801

Demirtaş, H., Comert, M., \& Ozer, N. (2011). Öğretmen adaylarının öz yeterlik inançları ve öğretmenlik mesleğine ilişkin tutumları. Ĕgitim ve Bilim, 36(159), 96-111.

Doğan, T., \& Coban, A. E. (2009). Eğitim fakültesi öğrencilerinin öğretmenlik mesleğine yönelik tutumları ile kaygı düzeyleri arasındaki ilişkinin incelenmesi. Eğitim ve Bilim, 34(153), 157-168.

Erkuş, A., Sanlı, N., Baglı, M. T., \& Guven, K. (2000). Öğretmenliğe ilişkin tutum ölçeği geliştirilmesi. Eğitim ve Bilim. 25(116), 27-32. 
Ferla, J., Valcke, M., \& Cai, Y. (2009). Academic self-efficacy and academic self-concept: Reconsidering structural relationships. Learning and Individual Differences, 19(4), 499-505. http://dx.doi.org/10.1016/j.lindif.2009.05.004

Fortier, M. S., Vallerand, R. J., \& Guay, F. (1995). Academic motivation and school performance: Toward a structural model. Contemporary Educational Psychology, 20(3), 257-274. http://dx.doi.org/10.1006/ceps.1995.1017

Garvis, S., Fluckiger, B., \& Twigg, D. (2011). Exploring the beliefs of commencing early childhood education graduate students: providing insights to improve teacher education programs. Australian Journal of Teacher Education, 37(1), 6. http://dx.doi.org/10.14221/ajte.2012v37n1.3

Huang, C. (2012). Gender differences in academic self-efficacy: a meta-analysis. European Journal of Psychology of Education, 28(1), 1-35. http://dx.doi.org/10.1007/s10212-011-0097-y

Ipek, C., \& Camadan, F. (2012). Primary teachers' and primary pre-service teachers' self-efficacy beliefs and attitudes toward teaching profession. International Journal of Human Sciences, 9(2), 1206-1216.

Jerusalem, M., \& Schwarzer, R. (1981). General self-efficacy scale. Freie Universitat, Berlin, Gesundheitspsychologie, http://web. fuberlin. de/gesund/skalen, 1993, 2000.

Johnson, G., \& Howell, A. (2005). Attitude toward instructional technology following required versus optional WebCT usage. Journal of Technology and Teacher Education, 13(4), 643-654.

Jong, C., \& Hodges, T. (2013). The influence of elementary preservice teachers' mathematical experiences on their attitudes towards teaching and learning mathematics. International Electronic Journal of Mathematics Education, $8(2-3), 100-122$.

Karagüven, U. M. (2012). Akademik motivasyon ölçeğinin Türkçeye adaptasyonu. Kuram ve Uygulamada Eğitim Bilimleri, 12(4), 2599.

McGeown, S. P., Putwain, D., Geijer Simpson, E., Boffey, E., Markham, J., \& Vince, A. (2014). Predictors of adolescents' academic motivation: Personality, self-efficacy and adolescents' characteristics. Learning and Individual Differences, 32, 278-286. http://dx.doi.org/10.1016/j.lindif.2014.03.022

Mojavezi, A., \& Tamiz, M. P. (2012). The Impact of teacher self-efficacy on the students' motivation and achievement. Theory and Practice in Language Studies, 2(3), 483-491. http://dx.doi.org/10.4304/tpls.2.3.483-491

Murphy, C., \& Smith, G. (2012). The impact of a curriculum course on pre-service primary teachers' science content knowledge and attitudes towards teaching science. Irish Educational Studies, 31(1), 77-95. http://dx.doi.org/10.1080/03323315.2011.634061

Núñez, J., Martín-Albo, J., Navarro, J., \& Suárez, Z. (2010). Adaptation and validation of the Spanish version of the academic motivation scale in post-compulsory secondary education students. Estudios De Psicologia, 31(1), 89-100. http://dx.doi.org/10.1174/021093910790744590

Opdenakker, M. C., Maulana, R., \& den Brok, P. (2012). Teacher-student interpersonal relationships and academic motivation within one school year: Developmental changes and linkage. School Effectiveness and School Improvement, 23(1), 95-119. http://dx.doi.org/10.1080/09243453.2011.619198

Özder, H., Konedralı, G., \& Zeki, C. P. (2010). Öğretmen adaylarının öğretmenlik mesleğine yönelik tutumlarının çeşitli değişkenler açısından incelenmesi. Kuram ve Uygulamada Eğitim Yönetimi Dergisi, 16(2), 253-275.

Pajares, M. F. (1992). Teachers' beliefs and educational research: Cleaning up a messy construct. Review of educational research, 62(3), 307-332. http://dx.doi.org/10.3102/00346543062003307

Pintrich, P. R. (2003). A motivational science perspective on the role of student motivation in learning and teaching contexts. Journal of educational Psychology, 95(4), 667. http://dx.doi.org/10.1037/0022-0663.95.4.667

Raths, J. (2001). Teachers' Beliefs and Teaching Beliefs. Early Childhood Research and Practice, 3(1). http://ecrp.uiuc.edu/v3n1/raths.html

Rimm-Kaufman, S. E., \& Sawyer, B. E. (2004). Primary-grade teachers' self-efficacy beliefs, attitudes toward teaching, and discipline and teaching practice priorities in relation to the" responsive classroom" approach. The Elementary School Journal, 104(4), 321-341. http://dx.doi.org/10.1086/499756

Şahin, H., \& Çakar, E. (2011). Egitim fakultesi ogrencilerinin öğrenme stratejileri ve akademik güdülenme düzeylerinin akademik başarıya etkisi. Journal of Turkish Educational Sciences, 9(3), 519-540.

Schunk, D. H., \& Pajares, F. (2002). The development of academic self-efficacy. In A. Wigfield \& J. S. Eccles (Eds.), Development of achievement motivation (pp. 16-32). San Diego, CA: Academic Press. http://dx.doi.org/10.1016/B978-012750053-9/50003-6 
Skaalvik, E. M., \& Skaalvik, S. (2007). Dimensions of teacher self-efficacy and relations with strain factors, perceived collective teacher efficacy, and teacher burnout. Journal of Educational Psychology, 99(3), 611. http://dx.doi.org/10.1037/0022-0663.99.3.611

Sundberg, B., \& Ottander, C. (2013). The conflict within the role: a longitudinal study of preschool teachers' developing competence in and attitudes towards science teaching in relation to developing a professional role. Journal of Early Childhood Teacher Education, 34(1), 80-94. http://dx.doi.org/10.1080/10901027.2013.758540

Vallerand, R. J., Pelletier, L. G., Blais, M. R., Briere, N. M., Senecal, C., \& Vallieres, E. F. (1992). The academic motivation scale: A measure of intrinsic, extrinsic, and amotivation in education. Educational and Psychological Measurement, 52(4), 1003-1017. http://dx.doi.org/10.1177/0013164492052004025

Vansteenkiste, M., Lens, W., \& Deci, E. L. (2006). Intrinsic versus extrinsic goal contents in self-determination theory: Another look at the quality of academic motivation. Educational Psychologist, 41(1), 19-31. http://dx.doi.org/10.1207/s15326985ep4101_4

Vecchione, M., Alessandri, G., \& Marsicano, G. (2014). Academic motivation predicts educational attainment: Does gender make a difference?. Learning and Individual Differences, 32, 124-131.

Wagner, E., \& Szamosközi, S. (2012). Effects of direct academic motivation-enhancing intervention programs: A meta-analysis. Journal of Evidence-Based Psychotherapies, 12(1), 85.

Walker, C. O., Greene, B. A., \& Mansell, R. A. (2006). Identification with academics, intrinsic/extrinsic motivation, and self-efficacy as predictors of cognitive engagement. Learning and Individual Differences, 16(1), 1-12. http://dx.doi.org/10.1016/j.lindif.2005.06.004

Wilkesmann, U., Fischer, H., \& Virgillito, A. (2012). Academic Motivation of Students-the German Case. Zentrum für Weiterbildung.

Yi-Hsiang, P. (2014). Relationships among teachers' self-efficacy and students' motivation, atmosphere, and satisfaction in physical education. Journal of Teaching in Physical Education, 33(1), 68-92. http://dx.doi.org/10.1123/jtpe.2013-0069

Yılmaz, M., Gürçay, D., \& Ekici, G. (2007). Akademik Özyeterlik Ölçeginin Türkçeye Uyarlanması.Hacettepe Üniversitesi Egitim Fakültesi Dergisi, 33, 253-259.

Zajacova, A., Lynch, S. M., \& Espenshade, T. J. (2005). Self-efficacy, stress, and academic success in college. Research in Higher Education, 46(6), 677-706. http://dx.doi.org/10.1007/s11162-004-4139-z

\section{$(\mathrm{cc}) \mathrm{BY}$}

This work is licensed under a Creative Commons Attribution 3.0 License. 